\title{
Pengaruh Rebusan Daun Kersen Terhadap Kadar Glukosa Darah Penderita Diabetes Melitus Tipe 2 Di Wilayah Kerja Puskesmas Bontobahari
}

\author{
Edison Siringoringo ${ }^{1}$ \\ Asri $^{2}$ \\ Safruddin ${ }^{3}$
}

\author{
${ }^{1,2}$ Prodi Profesi Ners Stikes Panrita Husada Bulukumba, Indonesia \\ ${ }^{3}$ Prodi S1 Keperawatan, Stikes Panrita Husada Bulukumba,Indonesia
}

\section{Alamat Koresponden :}

Asri

BTN IIN Citra Lestari 2

Kecamatan Gantarang

Kabupaten Bulukumba

Hp. 085242199519

Email: asripanrita86@gmail.com 


\begin{abstract}
ABSTRAK
Diabetes mellitus merupakan salah satu masalah kesehatan yang besar di dunia. Diabetes mellitus atau yang biasa disebut dengan penyakit gula (kencing manis) adalah suatu penyakit yang menyebabkan tubuh penderita tidak mampu mengendalikan tingkat gula (glikosa) di dalam darahnya. Pada saat sekarang ini, banyak masyarakat yang melakukan pengobatan dengan memanfaatkan tanaman sebagai obat tradisional. Salah satunya adalah daun kersen. Daun kersen dipercaya dapat meurunkankadar glukosa darah penderita diabetes mellitus tipe II. Tujuan penelitian ini adalah untuk mengetahui Pengaruh Rebusan Daun KersenTerhadap kadar Glukosa Darah pada penderita Diabetes Tipe II Di Wilayah Kerja Puskesmas Bontobahari Tahun 2020. Desain penelitian yang digunakan dalam penelitian ini adalah desain penelitian kuantitaf dengan metode tru-eksperimen (eksperimen murni) dengan rancangan pre post test control group design. Sampel yang digunakan sebanyak 38 resonden, dengan tekhnik pengambilan sampel yaitu tekhnik probability sampling dengan simple random sampling. Analisa data dalam penelitian ini menggunakan uji statistic uji T Tidak Berpasangan. Hasil analisa menggunakan uji statistic uji T tidak berpasangan didapatkan nilai $p=0,000(p \leq 0,05)$, yang berarti Ho ditolak dan Ha diterima.. Ada pengaruh Rebusan Daun KersenTerhadap kadar Glukosa Darah pada penderita Diabetes Tipe II Di Wilayah Kerja Puskesmas Bontobahari Tahun 2020.
\end{abstract}

Kata Kunci: Daun Kersen, Glukosa Darah Diabetes Melitus

\begin{abstract}
Diabetes mellitus is one of the biggest health problems in the world. Diabetes mellitus or what is commonly called diabetes (diabetes) is a disease that causes the patient's body to be unable to control the level of sugar (glycose) in the blood. At this time, many people are doing treatment by using plants as traditional medicine. One of them is cherry leaves. Kersen leaves are believed to reduce blood glucose levels in type II diabetes mellitus sufferers. The purpose of this study was to determine the effect of Kersen leaf decoction on blood glucose levels in patients with Type II diabetes in the Bontobahari Community Health Center in 2020. The research design used in this study was a quantitative research design with a tru-experimental method (pure experiment) with a pre post design. Test control group design. The sample used was 38 respondents, with a sampling technique that is probability sampling with simple random sampling. Analysis of the data in this study using the Unpaired $T$ test statistical test. The results of the analysis using the unpaired T test statistical test obtained $p$ value $=0.000$ ( $p \leq 0.05)$, which means that Ho is rejected and Ha is accepted. There is an effect of Kersen Leaf Decoction on Blood Glucose levels in people with Type II Diabetes in the Bontobahari Community Health Center Work Area. 2020.
\end{abstract}

Keywords: Kersen Leaf, Diabetes Mellitus Blood Glucose 


\section{PENDAHULUAN}

Diabetes mellitus merupakan salah satu masalah kesehatan yang besar di dunia. Diabetes mellitus atau yang biasa disebut dengan penyakit gula (kencing manis) adalah suatu penyakit yang menyebabkan tubuh penderita tidak mampu mengendalikan tingkat gula (glikosa) di dalam darahnya. Lebih dari satu juta orang meninggal disebabkan karena diabetes mellitus (IIDF 2019). Seiring dengan berkembangnya ilmu pengetahuan dan tekhnologi serta terjadinya perubahan gaya hidup social dan ekonomi akibat dari modernisasi, menjadi salah satu penyebab meningkatnya suatu penyakit degeneratif yang mengakibatkan kematian. Salah satu yang harus diwaspadai adalah penyakit diabetes mellitus.

Prevalensi kejadian diabetes mellitus terus meningkat dari tahun ketahun. Organisasi kesehatan dunia World Health Organization (WHO 2019) memperkirakan pada tahun 2000 berjumlah 171 juta orang menjadi 366 juta pada tahun 2030. Indonesia berada pada peringkat ke-4 di dunia terbanyak penderita diabetes melitusnya setelah Tiongkok, India dan Amerika Serikat. Dari data (RISKESDAS 2018) prevalensi diabetes mellitus berdasarkan diagnose dokter pada penduduk semua umur menurut provinsi sebanyak 1.017.290 jiwa. Provinsi
Sulawesi Selatan menduduki peringkat ke 7, yaitu sekitar 33.693 penduduk yang menderita penyakit diabetes mellitus. Data di atas menunjukkan bahwa kejadian diabetes memang menjadi masalah yang serius. Hal ini disebabkan karena jumlah penderita diabetes mellitus yang sangat banyak dan mengalami peningkatan.

Berbagai macam dampak buruk dapat terjadi karena diabetes mellitus. Diantaranya amputasi, kebutaan, kerusakan pada ginjal, bahkan diabetes mellitus dapat menyebabkan kematian. Menurut (WHO 2019) diabetes mellitus menyebabkan hampir 4 juta kematian disetiap tahunnya dan diperkirakan 629 juta orang yang hidup dengan diabetes pada tahun 2045. Orang yang hidup dengan penyakit diabetes mellitus memiliki resiko terkena berbagai macam komplikasi yang mengancam jiwa. Diabetes beserta dengan komplikasinya harus ditangani dengan baik. Jika tidak ditangani dengan baik, penderita akan keluar masuk rumah sakit dan akan menyebabkan kematian dini. (IIDF 2019). Dengan demikian diabetes mellitus merupakan masalah yang serius dan perlu ditangani melalui upaya pencegahan.

Pemerintah telah melakukan upaya pencegahan dengan menerapkan program senam prolanis. Akan tetapi upaya tersebut tidak menurunkan jumlah penderita 
diabetes mellitus. Sehingga banyak masyarakat yang melakukan pengobatan dengan memanfaatkan tanaman sebagai obat tradisional. Fenomena yang terlihat dimasyarakat, banyak penderita diabetes melitus yang mengkonsumsi daun kersen.

Di daerah Klasaman Kota Sorong telah dilakukan penelitian yang berjudul pengaruh rebusan daun kersen terhadap penurunan kadar gula darah sewaktu pada klien diabetes mellitus tipe II oleh (Norma and Nur 2019). Hasil penelitiannya menunjukkan ada pengaruh yang signifikan dalam pemberian rebusan daun kersen terhadap penurunan gula darah sewaktu penderita diabetes mellitus tipe II.

Diabetes tipe I disebabkan oleh kerusakan pankreas sehingga produksi insulin kurang. Agar tetap hidup, penderita diabetes perlu mendapatkan suntikan berupa hormone insulin secara rutin dan harus terjadwal. Berbeda dengan diabetes mellitus tipe II. Diabetes mellitus tipe II disebabkan oleh resistensi insulin dalam arti insulinnya cukup tetapi tidak bekerja dengan baik dalam mengontrol kadar gula darah. Itulah sebabnya pada penelitian ini berfokus kepada penderita diabetes tipe II yang tidak memiliki ketergantungan insulin karena jika diabetes tipe I yang diberikan rebusan daun kersen maka akan berdampak pada insulin yang diberikan.

Di dalam penelitian ini, peneliti menggunakan rebusan karena pada penelitian-penelitian sebelumnya belum pernah dilakukan penelitian selain menggunakan rebusan. Kecuali pada penelitian yang diberikan kepada hewan. Mereka menggunakan ekstrak daun kersen untuk diuji cobakan kepada tikus.

Dari pendataan awal yang dilakukan pada tanggal 24 januari 2020 di di wilayah Kerja Puskesmas Bontobahari yaitu pada tahun 2017 terdapat 563 penderita diabetes. Kemudian pada tahun 2018 terdapat 922 dan pada tahun 2019 meningkat menjadi 977 warga yang menderita diabetes mellitus. Penyebab terjadinya penyakit diabetes mellitus di wilayah tersebut adalah jenis kelamin, genetic, usia, obesitas serta pola hidup yang buruk. Sehingga hal tersebut menyebabkan dampak yang buruk kepada masyarakat.

Berdasarkan hasil penelitian yang dilakukan di wilayah kerja puskesmas Bontobahari, didapatkan adanya perbedaan kadar glukosa darah sebelum dan setelah diberikan perlakuan pada penderita diabetes mellitus tipe II. Pada kelompok intervensi terjadi penurunan kadar glukosa darah setelah diberikan perlakuan. Hal ini menunjukkan bahwa ada pengaruh yang signifikan rebusan daun kersen terhadap kadar glukosa darah penderita diabetes mellitus tipe II di wilayah kerja puskesmas Bontobahari.. 
Tujuan penelitian ini adalah untuk mengetahui Pengaruh Rebusan Daun KersenTerhadap kadar Glukosa Darah pada penderita Diabetes Tipe II Di Wilayah Kerja Puskesmas Bontobahari Tahun 2020.

\section{METODE PENELITIAN}

Desain penelitian yang digunakan dalam penelitian ini adalah desain penelitian kuantitaf dengan metode trueksperimen (eksperimen murni) dengan rancangan pre post test control group design. Pada desain ini responden penelitian dibagi secara random menjadi 2 kelompok. Satu adalah kelompok perlakuan sedangkan kelompok lain adalah kelompok control sebagai pembanding.

Populasi dalam penelitian ini adalah penderita diabetes mellitus tipe II di Wilayah Kerja puskesmas Bontobahari Jumlah sampel dalam penelitian ini sebanyak 38 responden. Tekhnik pengambilan sampel yang digunakan dalam penelitian ini adalah probability sampling dengan simple random sampling.

Instrument yang digunakan untuk pengumpulan data menggunakan lembar observasi yang diisi oleh peneliti. . Instrument yang digunakan dalam mengukur kadar glukosa darah adalah dengan pengkuruan bio-fisiologi dengan alat glucometer

Data dianalisis berdasarkan skala ukur dan tujuan penelitian dengan menggunakan perangkat lunak program komputerisasi. Data dianalisis secara : (1) Analisis Univariat, Analisis dilakukan untuk melihat proporsi. (2) Analisis Bivariat, Uji bivariat dilakukan untuk mencari hubungan antara variabel independen dan variabel dependen dengan uji yang digunakan adalah $T$ Tidak berpasangan bila memenuhi syarat. Kemaknaan yang diterima apabila $\mathrm{p}<$ 0,05 .

\section{HASIL}

Berdasarkan (Tabel 1) Jumlah responden pada penelitian ini berjumlah 38 responden dengan pembagian 2 kelompok diantaranya kelompok intervensi dan kelompok control. jenis kelamin perempuan lebih banyak dibandingkan jenis kelamin laki-laki, baik pada kelompok intervnesi maupun pada kelompok control yaitu sebanyak 73,7 \% pada kelompok intervensi dan 78,9\% pada kelompok control.

Usia yang paling banyak adalah lansia yaitu 94,7 \% pada kelompok intervensi dan 84,2 \% pada kelompok control dibandingkan dengan usia dewasa dan manula. Pekerjaan yang paling banyak adalah tidak bekerja/IRT yaitu 52,6 \% pada kelompok intervensi dan sama pada kelompok control. pendidikan yang paling banyak adalah pendidikan menengah yaitu $57,9 \%$ pada kelompok intervensi dan $52,7 \%$ pada kelompok control. 
Berdasarkan (Tabel 2 ) menunjukkan rata-rata (mean) kadar gula darah sebelum perlakuan pada kelompok intervensi 282,42 mg/dl (64,099). Hampir sama (homogen) pada kelompok control 262,95 mg/dl $(38,695)$ atau selisih mean 19,4. Sedangkan setelah diberikan perlakuan menunjukkan rata-rata (mean) kadar gula pada kelompok intervensi 210,05 mg/dl (40,539). Berbeda pada kelompok control yaitu $261,95 \mathrm{mg} / \mathrm{dl}(35,841)$ atau selisih mean meningkat menjadi 51,9.

Berdasarkan (Tabel 3) menunjukkan bahwa rata-rata (mean) kadar glukosa darah setelah perlakuan pada kelompok intervensi yaitu $210,05 \mathrm{mg} / \mathrm{dl}$ berbeda pada kelompok control 261,95 mg/dl. Hal ini menunjukkan bahwa dengan intervensi rebusan daun kersen dapat menurunkan kadar glukosa darah pada penderita diabetes mellitus tipe II. Hasil uji statistic (uji T Tidak Berpasangan) didapatkan nilai $\mathrm{p}=0,000 \quad(\mathrm{p} \leq 0,05)$, yang berarti Ho ditolak atau ada perbedaan rerata bermakna kadar glukosa darah sebelum dan setelah pemberian intervensi rebusan daun kersen pada penderita diabetes mellitus tipe II di wilayah kerja puskesmas Bontobahari.

\section{PEMBAHASAN}

Berdasarkan hasil penelitian yang dilakukan di wilayah kerja puskesmas Bontobahari, didapatkan adanya perbedaan kadar glukosa darah sebelum dan setelah diberikan perlakuan pada penderita diabetes mellitus tipe II. Pada kelompok intervensi terjadi penurunan kadar glukosa darah setelah diberikan perlakuan. Menunjukkan bahwa ada pengaruh yang signifikan rebusan daun kersen terhadap kadar glukosa darah penderita diabetes mellitus tipe II di wilayah kerja puskesmas Bontobahari.

Study saat ini menemukan bahwa terjadinya penurunan kadar glukosa darah setelah diberikan rebusan daun kersen. Penurunan kadar gukosa darah disebabkan karena kandungan yang berada pada daun kersen. Daun kersen memiliki kandungan yang dapat menurunkan kadar glukosa darah, diantaranya flavonoid, chalcone dan tanin. Senyawa flavonoid memiliki efek hipoglikemik dengan beberapa mekanisme, yaitu menghambat absorpsi glukosa, merangsang pelepasan dan sensitasi insulin, meningkatkan ambilan glukosa oleh jaringan perifer, serta perberan dalam pengaturan enzim-enzim dalam metabolism karbohidrat.

Chalcone dapat menurunkan kadar glukosa darah melalui mekanisme menaikkan sensitasi insulin, menurunkan glukogeonesis oleh hepar dan menaikkan kadar hormon glucagon-like polypeptide-1 sebagai regulator glukosa pada usus halus.

Tanin mampu menurunkan kadar glukosa darah dengan meningkatkan ambilan glukosa melalui aktivasi MAPK 
(Mitogen-Activated Protein Kinase) dan P13K (Phosphoinositide 3-Kinase). Hal ini didukung oleh penelitian yang dilakukan oleh (Airlangga and Asep 2018), yang mengatakan bahwa daun kersen memiliki beberapa kandungan yang dapat menurunkan kadar glukosa darah, diantaranya flavonoid, chalcone dan tanin.

Rebusan daun kersen terbukti dapat menurunkan kadar gula darah untuk penderita diabetes mellitus. Penurunan ini dapat disebabkan oleh kandungan dari Daun Kersen yaitu flavonoid. Senyawa dari flavonols yang diduga memiliki aktifitas dalam menurunkan kadar glukosa dalam darah adalah kuersetin. Dimana mekanisme kerja kuersetin dalam menurunkan kadar glukosa darah yakni menjaga sel $\beta$ pankreas tetap bekerja secara normal.

Selain itu flavonoid dapat merangsang penyerapan glukosa pada jaringan perifer dan mengatur kerja enzim yang terlibat dalam jalur metabolisme karbohidrat. Hal ini didukung oleh penelitian yang dilakukan oleh (Norma and Nur 2019) yang menemukan hasil penelitian bahwa ada pengaruh yang signifikan rebusan daun kersen terhadap kadar glukosa darah penderita diabetes mellitus tipe II.

Daun kersen juga mengandung senyawa saponin yang dapat menghambat penyerapan gula darah dari usus, sehingga karbohidrat tidak banyak diserap oleh usus. Hal ini didukung oleh penelitian yang dilakukan oleh (Roihatul and Musriana 2016) dengan hasil penelitian Rebusan daun kersen terbukti dapat menurunkan kadar gula darah dan dapat dijadikan obat herbal untuk penderita DM. Sesuai dengan hasil saat ini, penelitian ini juga didukung oleh penelitian (Fitriani, Nurlinda, and Asrina 2019) pada tahun 2019 dengan hasil penelitian terdapat efek pemberian air rebusan daun kersen terhadap penurunan kadar GDP penderita diabetes mellitus tipe II.

Selain dari pada itu, ada beberapa faktor yang mempengaruhi kadar glukosa darah penderita diabetes mellitus tipe II diantaranya faktor stress dan pola hidup. Pada responden yang diberikan intervensi berupa rebusan daun kersen dan memiliki pola hidup yang baik serta adaptasi stress yang baik, kadar glukosa darah responden tersebut akan menurun dengan jumlah yang banyak. Bukan hanya pada kelompok intervensi. Pada kelompok control responden yang memiliki pola hidup dan adaptasi stress yang baik juga mengalami penurunan kadar glukosa darah walaupun penurunannya hanya sedikit. (Hardianti, Haerani, and Amirullah 2018) menunjukkan hasil penelitian bahwa pola hidup, faktor stress, jenis kelamin dan umur sangat berpegaruh terhadap kadar glukosa darah. 
Peneliti berasumsi bahwa kadar glukosa darah penderita diabetes mellitus tipe II setelah diberikan rebusan daun kersen diakibatkan karena kandungan dari daun kersen. Faktor stress dan pola hidup seseorang berbeda-beda. Sehingga hal ini mempengaruhi hasil dari pemberian rebusan daun kersen terhadap kadar glukosa darah.

\section{KESIMPULAN}

Terdapat pengaruh rebusan daun kersen terhadap penurunan kadar glukosa darah pada penderita diabetes mellitus tipe II di Wilayah Kerja Puskesmas Bontobahari serta Terdapat perbedaan yang signifikan antara kelompok control dan kelompok intervensi yang telah diberikan rebusan daun kersen. Diharapkan untuk peneliti selanjutnya agar menambah waktu pemberian rebusan kepada responden.

\section{DAFTAR PUSTAKA}

Airlangga, Damara, and Sukohar Asep. 2018. "Efektivitas Infusa Daun Kersen (Muntingia Calabura Linn)Sebagai Antidiabetik." volume 05 .

Alimul, Hidayat A. Aziz. 2017. Metodologi Penelitian Keperawatan Dan Kesehatan. Jakarta Selatan: salemba medika.

Arum, Supartono, and Sudarmin. 2012. "ISOLASI DAN UJI DAYA ANTI MIKROBA EKSTRAK DAUN KERSEN.” jurnal MIPA 35(215).

Dharma, and Kusuma Kelana. 2011. Metode Penelitian Keperawatan. Jakarta: TIM.

Edison, Siringoringo, and Haerati. 2018. "FAKTOR-FAKTOR PENYEBAB KEKAMBUHAN PADA PASIEN
SKIZOFRENIA DI POLIKLINIK JIWA RSUD H. ANDI SULTHAN DG. RADJA KABUPATEN BULUKUMBA." 3(1): 24-40.

Ernawati, Waridah. 2017. Kamus Bahasa Indonesia. jakarta selatan: PT. KAWAH Media.

Fady, AF. 2015. Madu Dan Luka Diabetik. edisi 1. Yogyakarta: Gosyen Publishing.

Febrina, Mira, and Ses Filda Sari. 2019. "PENGARUH PEMBERIAN INFUSA DAUN KERSEN ( Muntingia Calabura L .) TERHADAP KADAR GLUKOSA DARAH MENCIT PUTIH ( Mus Musculus ) YANG DIBERI BEBAN GLUKOSA." 8(2).

Fitriani, Andi Nurlinda, and Andi Asrina. 2019. "EFEK AIR REBUSAN DAUN KERSEN ( MUNTINGIA CALABURA L ) TERHADAP KADAR GULA DARAH PENDERITA DIABETES MELLITUS TIPE II DI.” II(1): 1934.

Hardianti, Haerani, and Amirullah. 2018. "Analysis Of Risk Factors Of Mellitus Diabetes At Hospital H. Andi Sulthan Daeng Radja Bulukumba." (2025): 43-52.

Ihsan H. 2015. "Validitas Isi Alat Ukur Penelitian: Konsep Dan Panduan Penilaiannya." PEDAGOGIA.

IIDF. 2019. International Diabetes Federation IDF Diabetes Atlas 2019. http://www.idf.org/aboutdiabetes/facts-figures.

Kristiana, Fransisca. 2012. Awas Pankreas Rusak Penyebab Diabetes. Jakarta: Cerdas Sehat.

Kuntorini, Evi Mintowati, Setya Fitriana, and Dewi Astuti. 2013. "ANTIOKSIDAN EKSTRAK METANOL DAUN KERSEN ( Muntingia Calabura )." : 291-96.

Kusuma, Dharma Kelana. 2011. Metodologi Penelitian Keperawatan: Panduan Melaksanakan Dan 
Menerapkan Hasil Penelitian. Jakarta: CV. Trans Info Media.

Kusuma, H, and AH Nurarif. 2015. Aplikasi Asuhan Keperawatan Berdasarkan Diagnose NIC NOC. Edisi 1. Jogja:Jogjakarta: Mediacation.

Marjoni, Mhd Riza, Ari Devi Novita, and Kata Kunci. 2015. "Kandungan Total Fenol Dan Aktivitas Antioksidan Ekstrak Air Daun Kersen ( Muntingia Calabura L . ) Total Content of Fenol and Antioxidant Activity of The Aqueous Extract of Cherry Leaf ( Muntingia Calabura L . )." 23(3): 187-96.

Norma, and Hadrayanti Nur. 2019. "PENGARUH REBUSAN DAUN KERSEN TERHADAP PENURUNAN GULA DARAH SEWAKTU PADA KLIEN DIABETES MELITUS TIPE II DI WILAYAH KERJA PUSKESMAS KLASAMAN KOTA SORONG TAHUN 2018." preventive journal volume 03: 6-10.

Noviyanti, S.KM. 2015. Cara Cepat Usir Diabetes. Jakarta: NOTEBOOK.

Nursalam. 2016. Manajemen Keperawatan Aplikasi Dalam Praktik Keperawatan Profesional. edisi 5. jakarta: salemba medika.

Obi, Andareto. 2015. APOTIK HERBAL Di Sekitar Anda Solusi Pengobatan 1001 Penyakit Secara Alami Dan Sehat Tanpa Efek Samping. ed. Aryanti Rini Dwi. jakarta selatan: PUASTAKA ILMU SEMESTA.

Puspitasari, Anita Dwi, and Ririn Lispita Wulandari. 2017. "Aktivitas Antioksidan Dan Penetapan Kadar Flavonoid Total Ekstrak Etil Asetat Daun Kersen ( Muntingia Calabura )." 4(2): 167-75.
Rahmatul, Fitriani, and Rachmawati Siti. 2016. Cara Ampuh Tumpas Diabetes. Jagarasa-Jakarta: Medika.

RISKESDAS. 2018. "Laporan Nasional RISKESDAS 2018." Kementrian Kesehatan RI Badan Peneliti Pengembangan kesehatan.

Roihatul, Zahroh, and Musriana. 2016. "PEMBERIAN REBUSAN DAUN KERSEN MENURUNKAN KADAR GLUKOSA DARAH PASIEN DIABETES MELLITUS TIPE 2." jurnal of ners community volume 07.

Setiadi. 2013. KONSEP DAN PRAKTEK PENULISAN RISET KEPERAWATAN. Yogyakarta: GRAHA ILMU.

Subiyono. 2016. "Gambaran Kadar Glukosa Metode GOD-PAP (Glucose Oxidase-Peroxidase Aminoantypirin) Sampel Serum Dan Plasma EDTA (Ethylen Diamin Tetra Acetat)." Jurnal Poltekes Kemenkes vol.5.

Sugiyono. 2014. STATISTIK UNTUK PENELITIAN. Bandung: Alfabeta.

Sugiyono (2017). "Metode Penelitian Kuantitatif, Kualitatif, dan R\&D. Bandung, Alfabeta."

- 2017. Metode Penelitian Kuantitatif, Kualitatif Dan R\&D. Bandung: Alfabeta.

Sujono, Riyadi. 2011. Keperawatan Medikal Bedah. Yogyakarta: PUSTAKA BELAJAR.

Syamsuddin, Muriyati, Asdinar, and Sumarni. 2015. Pedoman Praktis Metode Penelitian Internal. Ponorogo: CV.Wade Group.

WHO. 2019. 21 Clinics in Laboratory Medicine Classification of Diabetes Mellitus.

—. "Sample Size Determination In Health Studies." 
Tabel 1 Distribusi Frekuensi Berdasarkan Karakteristik Responden

\begin{tabular}{|c|c|c|c|c|}
\hline \multirow{2}{*}{ Karasteristik Responden } & \multicolumn{2}{|r|}{ intervensi } & \multicolumn{2}{|c|}{ Control } \\
\hline & $\mathbf{F}$ & $\%$ & $\mathbf{F}$ & $\%$ \\
\hline \multicolumn{5}{|l|}{ Jenis Kelamin } \\
\hline Laki-Laki & 5 & $26,3 \%$ & 4 & $21,1 \%$ \\
\hline Perempuan & 14 & $73,7 \%$ & 15 & $78,9 \%$ \\
\hline \multicolumn{5}{|l|}{ Umur } \\
\hline Dewasa & 1 & $5,3 \%$ & 2 & $10,5 \%$ \\
\hline Lansia & 18 & $\begin{array}{l}94,7 \% \\
00 \%\end{array}$ & 16 & $84,2 \%$ \\
\hline Manula & 0 & & 1 & $5,3 \%$ \\
\hline \multicolumn{5}{|l|}{ Pekerjaan } \\
\hline Tidak Bekerja/ IRT & 10 & $52,6 \%$ & 10 & $52 \%$ \\
\hline Bekerja & 9 & $47,4 \%$ & 9 & $47,4 \%$ \\
\hline \multicolumn{5}{|l|}{ Pendidikan } \\
\hline Rendah & 8 & $42,1 \%$ & 9 & $47,3 \%$ \\
\hline Menengah & 11 & $57,9 \%$ & 10 & $52,7 \%$ \\
\hline Total & 19 & $100 \%$ & 19 & $100 \%$ \\
\hline
\end{tabular}

Tabel 2 . Distribusi kadar gula darah kelompok intervensi dan kelompok control sebelum dan setelah perlakuan

\begin{tabular}{cccccc}
\hline \multirow{2}{*}{ Kadar Gula Darah } & \multicolumn{2}{c}{ Intervensi } & \multicolumn{2}{c}{ Control } & \multirow{2}{*}{ S } \\
\cline { 2 - 5 } & Mean & SD & Mean & SD & \\
\hline Sebelum Perlakuan & 282,42 & 64,099 & 262,95 & 38,695 & 19,47 \\
Setelah Perlakuan & 210,05 & 40,539 & 261,95 & 35,841 & 51,9 \\
\hline
\end{tabular}

Tabel 3. Hasil analisa pengaruh rebusan daun kersen terhadap kadar glukosa darah penderita diabetes mellitus tipe II

\begin{tabular}{lll}
\hline Kadar glukosa darah setelah perlakuan & Mean $(\mathrm{SD})$ & $\mathrm{P}$ \\
\hline Kelompok Intervensi & $210,05(40,539)$ & 0,000 \\
Kelompok Control & $261,95(35,841)$ & \\
\hline
\end{tabular}

